\title{
EFFECTS OF SOIL TREATMENT WITH ABATTOIR EFFLUENT ON MORPHOLOGICAL AND BIOCHEMICAL PROFILES OF COWPEA SEEDLINGS (V.UNGUICULATA) GROWN IN GASOLINE POLLUTED SOIL
}

\author{
Achuba F. I. ${ }^{1}$ and Iserhienrhien L. O. ${ }^{2}$ \\ ${ }^{1,2}$ Department of Biochemistry, Delta State University, PMB 1, Abraka, Nigeria. \\ Corresponding author email: achubabch@yahoo.com \\ (Received: $22^{\text {nd }}$ October, 2017; Accepted: $3^{\text {rd }}$ December, 2017)
}

ABSTRACT

\begin{abstract}
The effects of abattoir wastewater treated soil on morphological and biochemical profiles of cowpea seedlings (Vigna unguiculata) grown in gasoline polluted soil was studied. Percentage germination, shoot length, root length and leaf area of cowpea seedlings grown in gasoline treated soil decreased significantly $(\mathrm{P}<0.05)$ when compared to the control. Moreover, gasoline contaminated soil significantly $(\mathrm{p}<0.05)$ decreased levels of total sugar, total protein, total amino acids, total chlorophyll, chlorophyll $\mathrm{a}$ and $\mathrm{b}$, and $\beta$-carotene contents of the leaves, as well as significant $(\mathrm{p}<0.05)$ decrease in the activities of $\alpha$-amylase and starch phosphorylase in the cotyledon compared to seedlings in the control. Cowpea seedlings grown in gasoline contaminated soil also showed alterations in antioxidant enzymes when compared to the control. However, treatment of gasoline contaminated soils with abattoir wastewater (AWW) substantially improved the growth parameters, chlorophyll and $\beta$-carotene contents of the cowpea seedlings. The activities of $\alpha$-amylase and starch phosphorylase, in addition to the antioxidant enzymes were considerably enhanced by AWW treatment. These findings showed in clear terms that abattoir wastewater may be a suitable manorial material for remediating gasoline contaminated soils as well as mitigate toxic effects of gasoline on exposed plants.
\end{abstract}

Keywords: Abattoir, Cowpea, Amylase, Phosphorylase, Antioxidants

\section{INTRODUCTION}

Gasoline, which is also called premium motor spirit (PMS), is a complex mixture of organic compounds obtained by the fractional distillation of crude oil and further enhanced by a variety of additives and blending agents (Eyidogan et al., 2010). The composition of gasoline varies widely, depending on the crude oil used and the refining process adopted (IARC, 1989). Gasoline can contaminate the environment from various industrial operations as well as accidental spill from oil tankers due to bad roads and through improper disposal by mechanics (Tyczkowsk1, 1993; Michalcewicz, 1995; Odjegba and Sadiq, 2002; Adam et al., 2002; Nwaogu et al., 2008; Liu et al., 2009; Maliszewska-Kordybach et al., 2009).

Soil polluted with petroleum hydrocarbons is devoid of water and oxygen as well as shortage of available forms of carbon, nitrogen and phosphorus (Wyszkowska and Kucharski, 2000; Wyszkowski and Ziolkowska, 2008). This reduces the ability of the soil to support living organisms present in it as well as its inability to carry out biochemical activities (Agbogidi and Eshegbeyi, 2006; Makoi and Ndakidemi, 2008; Achuba, 2014; Achuba and Okoh, 2014; Alrumman et al 2015).
Petroleum hydrocarbons have been described as a phytochemical substance (Peretiemo-clarke and Achuba, 2007). Previous studies indicated that petroleum induced changes in the macromolecular composition of plants (Rowland et al., 1988; Schmeink and Wild, 1990; Anoliefo and Edegbai, 2000). These changes include increase in total soluble sugars (Achuba, 2006) and decrease in photosynthetic pigments such as chlorophyll a and b and carotenoids (Agrawal, 1992; Keller and Lamprecht, 1995; Seklemora et al., 2001; Odjegba and Sadiq, 2002; Ye and Tam, 2007; Adedokun and Ataga, 2007; PeretiemoClarke and Achuba, 2007; Wang et al., 2011; Amal et al., 2012 ). Moreover petroleum pollution leads to alterations in plants morphological indices (Sun et al., 2004; Nioku et al., 2008a), reduction in the activities of starch phosphorylase and $\alpha$-amylase (Achuba, 2006; Achuba and Okoh, 2014) and alterations in oxidative stress indicators (Achuba, 2014).

The degradation of petroleum hydrocarbons is very slow in natural environment which is occasioned by nutritional imbalance created by oil spill (Ijah and Ndana, 2003). Earlier studies have employed different methods to restore gasoline 
polluted soil by the addition of microorganisms, organic and inorganic fertilizers and tilling (Ismailov, 1985; Bartha, 1986; Leahy and Colwell 1990; Ijah and George, 1998; Ijah and Antai, 2003; Iquatt et al., 2006). However, inorganic fertilizers are very expensive; hence the use of organic wastes (Leahy and Colwell, 1990; Adeleye, 1991; Ijah and Antai, 2003; Ukpaka and Edwin, 2013). Works that utilize abattoir wastewater as a suitable inexpensive tool in mitigating the toxic effect of gasoline on cowpea seedlings grown on gasoline contaminated soil has not been carried out. Cowpea is widely cultivated and it is one of the staple foods of the people of the Niger delta area of southern Nigeria whose farm lands are heavily polluted with petroleum hydrocarbon. Therefore this study investigated the morphological and metabolic indices of cowpea seedlings grown on abattoir wastewater-treated gasolinecontaminated soil

\section{MATERIALS AND METHODS}

\section{Chemicals and Reagents}

The gasoline used for this study was obtained from Warri Refining and Petrochemical Company, Ekpan, Warri, Nigeria. The various chemicals (analytical grade) that were used for this study were products of Randox Laboratories Ltd, Antrim, United Kingdom.

\section{Collection of materials}

Seeds of Vigna unguiculata (L) (IT845-2246-4 accession) were obtained from International Institute of Tropical Agriculture (IITA) Ibadan, Nigeria. The Seeds were subjected to floatation in order to ascertain that the seeds were intact and potentially viable. Seeds that did not float on water were assumed to be viable and were used for the experiment. The sandy loam soil of known composition (Achuba and Okoh, 2014) was used for this study. The physicochemical parameter of the sun-dried and sieved soil was published earlier (Achuba and Okoh, 2014). The abattoir wastewater used was randomly collected from a local slaughterhouse in Obiaruku, Delta State, Nigeria using a 10 litre capacity container. The container drew part of the wastewater running off the drainage system just as it was leaving the slaughter pavement. The physicochemical parameter of the abattoir effluent was published previously (Achuba and Ekute, 2017)

\section{Preliminary Assessment of Abattoir Wastewater on Plant Growth}

A pretreatment assessment was carried out which established that $40 \mathrm{ml}$ of abattoir wastewater used had a stimulating effect on plant growth parameters in cowpea seedlings when compared to other volumes of abattoir wastewater treatments $(10 \mathrm{ml}, 20 \mathrm{ml}, 30 \mathrm{ml}, 50 \mathrm{ml}, 60 \mathrm{ml}, 80 \mathrm{ml}$ and $100 \mathrm{ml}$ ) (Achuba and Ekute, 2017).

\section{Experimental Design}

Sieved soil (1600.0g) was added to each of the 100 planting bags and divided into two experimental series. Series 'A' treated only with gasoline and Series 'B' treated with gasoline and abattoir effluent ( $40 \mathrm{ml}$ each) as determined from a prior study. Each series was divided into seven groups with each group having five replicates.

In series A, the soil in each bag (Groups 1 to 7) was treated with gasoline at these concentrations $0.10 \%, 0.25 \%, 0.50 \%, 1.00 \%, 1.50 \%, 2.00 \%$ and $0.00 \%(\mathrm{v} / \mathrm{w})$ respectively. To prepare the first group, gasoline $(1.6 \mathrm{ml})$ was added to the soil $(1.6$ $\mathrm{kg}$ ) and mixed well with hand. The procedure was used with appropriate volumes of gasoline to prepare other treatments. The quantity of soil commensurable to the size of the planting polybag was earlier determined (Achuba and Okoh, 2014). Series B had same treatments and filtered abattoir effluent $(40 \mathrm{ml})$ added to the soil in each bag. Five seeds of the $V$. unguiculata were sown in each test bag at an approximate depth of 2 $.0 \mathrm{~cm}$. Each bag was watered daily (morning and evening), to keep the soil wet and germination monitored every four days. After the 12th day, seeds which failed to germinate were regarded as not healthy (Achuba, 2006)

\section{Determination of Growth Parameters}

Germination was expressed in percentage. The equation used to calculate the germination percentage is: Germination percent $=$ seed germinated/total seeds x 100 (Njoku et al., 2008a). Growth parameters (root length, shoot length) were measured with a metre rule. To determine the root length, each polybag was destroyed with soil intact. The soil containing the seedlings was then placed under slow- running tap water. This was to 
avoid damage to the roots. The roots were then measured with a metre rule from the tip to the base of the soil. The stems were measured from the base of the soil to the apex of the stem. The leaf area was calculated by measuring the longest and widest regions of each leaf used. The length and width of the leaf multiplied and standardized by multiplying with a correction factor

\section{Determination of Starch Degrading Enzymes.}

The alpha-amylase assay was carried out by the method of Gupta et al., (2003) using the supernatant obtained from the homogenization and subsequent centrifugation (at $3000 \mathrm{~g}$ ) of filtrate obtained from cowpea cotyledons $(0.50 \mathrm{~g})$ collected from the seedlings four days after planting. The activity of alpha- amylase was calculated using the formula proposed by Xiao et al., (2006). Singh and Steinnes (1976) method was used for the determination of Starch Phosphorylase

\section{Determination of Total Sugar Content, Amino Acid and Total Protein}

After twelve days of planting, leaves were collected and the leaf homogenates were prepared as described by Achuba (2006) The sugar content was determined as described by Tietz (1982).Total amino acid was determined using the ninhydrin procedure as earlier described (Achuba 2006). Lowry et al., (1951) method was used for the determination total soluble protein.

\section{Determination of Photosynthetic Pigments}

The leaves $(1.0 \mathrm{~g})$ of twelve- day -old seedlings were taken into the mortar, followed by the addition of $96 \%$ methanol and homogenized with pestle. The homogenate was then centrifuged at $2500 \mathrm{rpm}$ for ten minutes. Chlorophylls were determined by the method of Lichtenthaler (1987).The level of carotenoid was determined according to Duxbury and Yentsch (1956).

\section{Evaluation of Oxidative Stress Markers}

Leaves were collected after twelve days of planting for the determination of oxidative stress markers. Lipid peroxidation was determined according to the method of Heath and Packer (1968). Superoxide dismutase (SOD) activity was determined by the method of Misra and Fredorich
(1972), which was based on the inhibitory effect of SOD on epinephrine auto oxidation. MnSOD and $\mathrm{Cu} / \mathrm{ZnSOD}$ activities were assayed according to the method of Crapo et al (1978). Catalase activity was measured according to Rani et al., (2004). The method outlined by Achuba (2010) was used to estimate xanthine oxidase activity.

\section{Statistical Analysis}

Means were subjected to analysis of variance (ANOVA) and post Hoc Fisher's test for multiple comparisons of control and gasoline exposed seedlings as well as gasoline exposed seedling and seedlings grown in abattoir wastewater treated gasoline contaminated soils. This was done with the statistical package for social science (SPSS, version 20). Significance level was set at $\mathrm{p}$ values $<$ 0.05 . The results were expressed as Mean \pm SD.

\section{RESULTS AND DISCUSSION}

The present study showed that treatment of soil with gasoline reduced the growth parameters of cowpea seedlings (Figure 1). This result agrees with previous report (Adedokun and Ataga, 2007). Nevertheless, treatment of contaminated soil with abattoir wastewater (AWW) significantly $(p<0.05)$ increased the values of the growth parameters when compared to seedlings grown in gasoline contaminated soil alone. This is consistent with previous report (Ekpo and Nya. 2012) which indicated that poultry droppings improved the growth parameters of various seedlings. Abattoir wastewater like other organic wastes such as cow dung and poultry droppings is a good source of organic manure and essential nutrients like nitrate and phosphate. Besides, abattoir wastewater contains hydrocarbonutilizing micro-organisms (Umanu and Owoseni 2013) whose activities increase soil fertility when carbon content in hydrocarbon is used as source of energy .This may explain the basis for the improved performance of cowpea seedlings exposed to soil co-treated with gasoline and abattoir wastewater.

Contamination of soil with gasoline decreased the content of protein, amino acids and sugar in the leaves of exposed cowpea seedlings relative to the control (Table 1). This indicates environmentallyinduced metabolic imbalances (Al-Hawas et al., 2012; Olubodun and Eriyamremu, 2015). 
Notwithstanding, treatment with abattoir wastewater (AWW) significantly increased the level of these biomolecules when compared to the gasoline alone groups. Sivaraj et al (2014) had earlier reported that poultry droppings in diesel polluted soil improved the concentrations of macromolecules in sunflower seedlings.
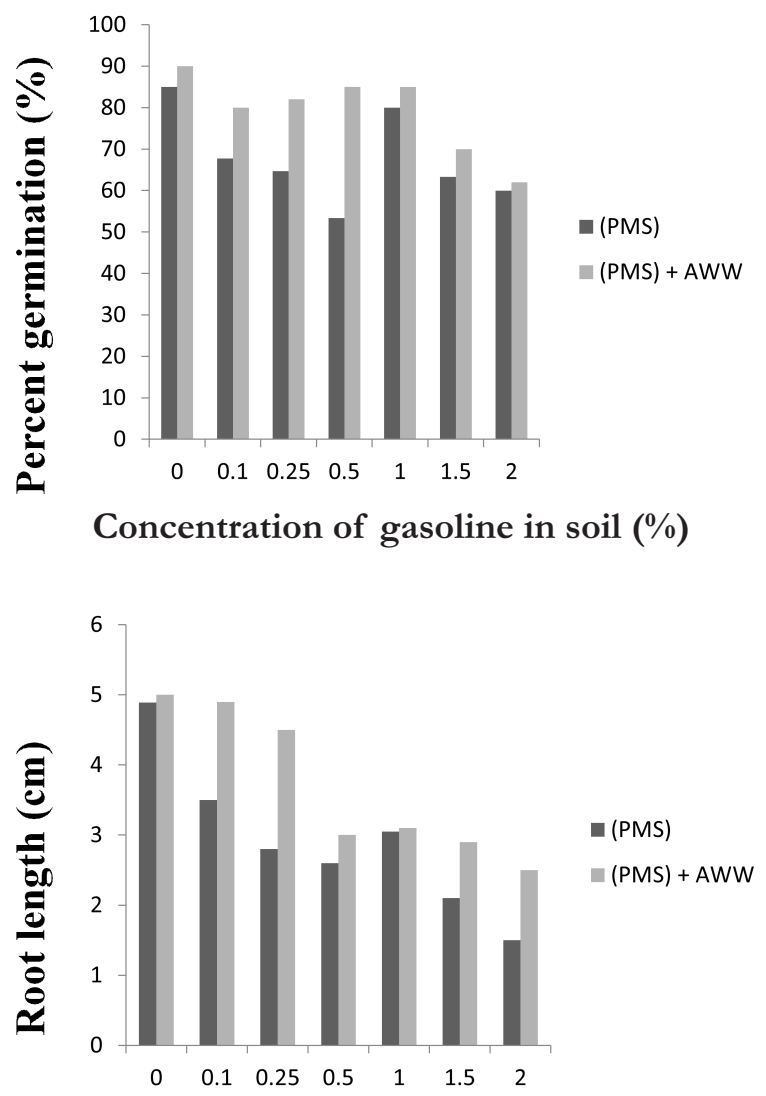

Concentration of gasoline in soil (\%)

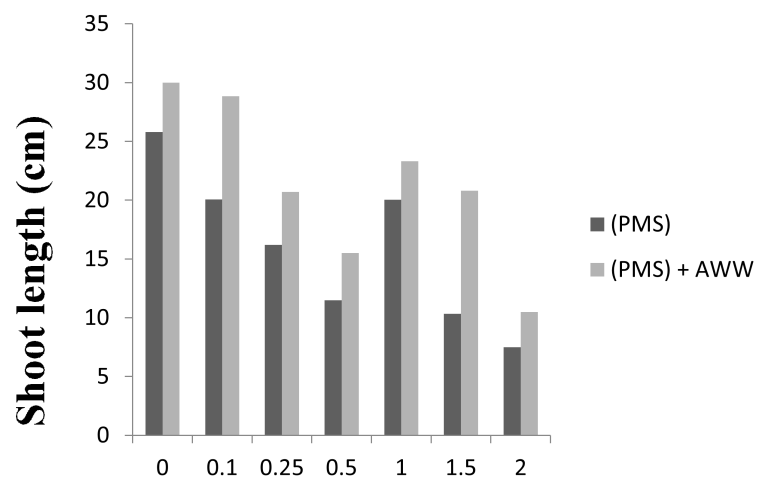

Concentration of gasoline in soil $(\%)$

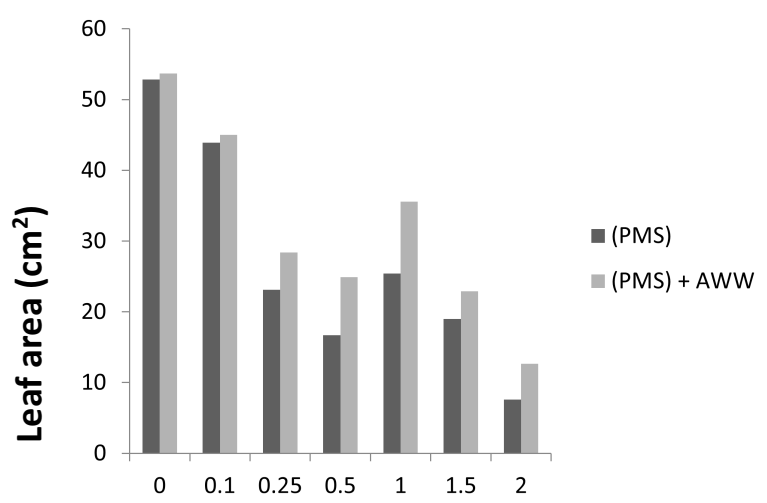

Concentration of gasoline in soil (\%)

Figure 1: Effect of abattoir waste water addition to gasoline-treated soil on morphological parameters of cowpea seedlings grown on such soil

Table 1: Effect of abattoir wastewater (AWW) addition to gasoline-treated soil on the level of sugar, protein, and amino acid in the leaves of cowpea seedlings grown on such soil

\begin{tabular}{ccccccc} 
Gasoline concentration & \multicolumn{3}{c}{ Total Sugar $(\mathbf{m g} / \mathbf{g}) \mathbf{n}=\mathbf{5}$} & \multicolumn{2}{c}{ Total Protein $(\mathbf{m g} / \mathbf{g}) \mathbf{n}=5$} & Total Amino Acid(mg/g) $\mathbf{n}=5$ \\
\cline { 2 - 7 } in soil $(\% \mathbf{v} / \mathbf{w} \mathbf{~ m l} / \mathbf{g})$ & PMS & PMS +AWW & PMS & PMS+AWW & PMS & PMS+AWW \\
0.00 & $5.45 \pm 0.01$ & $6.05 \pm 0.81$ & $5.40 \pm 0.25$ & $5.60 \pm 0.25$ & $5.78 \pm 0.15$ & $5.80 \pm 0.25$ \\
0.10 & $5.65 \pm 0.05^{\mathrm{a}}$ & $5.70 \pm 0.47^{\mathrm{a}}$ & $5.50 \pm 0.18^{\mathrm{a}}$ & $6.03 \pm 0.75^{\mathrm{ab}}$ & $5.95 \pm 0.21^{\mathrm{ab}}$ & $5.97 \pm 0.10^{\mathrm{ab}}$ \\
0.25 & $6.02 \pm 0.03^{\mathrm{a}}$ & $6.18 \pm 0.92^{\mathrm{ab}}$ & $6.12 \pm 0.91^{\mathrm{ab}}$ & $6.16 \pm 0.50^{\mathrm{ab}}$ & $6.20 \pm 0.06^{\mathrm{ab}}$ & $6.31 \pm 0.06^{\mathrm{ab}}$ \\
0.50 & $6.55 \pm 0.89^{\mathrm{ab}}$ & $6.90 \pm 0.76^{\mathrm{ab}}$ & $6.20 \pm 0.49^{\mathrm{ab}}$ & $6.30 \pm 0.50^{\mathrm{ab}}$ & $6.50 \pm 0.06^{\mathrm{ab}}$ & $7.10 \pm 0.10^{\mathrm{ab}}$ \\
1.00 & $5.95 \pm 0.94^{\mathrm{a}}$ & $6.25 \pm 0.25^{\mathrm{ab}}$ & $5.90 \pm 0.61^{\mathrm{ab}}$ & $6.17 \pm 0.70^{\mathrm{ab}}$ & $5.30 \pm 0.06$ & $5.42 \pm 0.15$ \\
1.50 & $5.30 \pm 0.90$ & $6.05 \pm 0.35^{\mathrm{a}}$ & $5.08 \pm 0.67$ & $5.19 \pm 0.21$ & $5.12 \pm 0.06$ & $5.25 \pm 0.15$ \\
2.00 & $4.25 \pm 0.65$ & $5.31 \pm 0.16$ & $4.59 \pm 0.70$ & $4.67 \pm 0.24$ & $4.00 \pm 0.06$ & $4.10 \pm 0.15$ \\
\hline
\end{tabular}

Results are expressed as mean \pm SD of five determinations. $a=$ values significantly higher than those of control at $\mathrm{P}<0.05 ; \mathrm{b}=$ values significantly higher than the corresponding gasoline treatment; $\mathrm{n}=$ number of seedlings used per assay 
In this study exposure to gasoline treated soil decreased the levels of chlorophylls and $\beta$ carotene in $V$. unguiculata (Table 2). Similar results were reported by Achuba (2006) and Al-Hawas et al (2012). Again, treatment of gasoline contaminated soil with abattoir wastewater significantly improved the concentrations of the aforementioned molecules. Previous studies that employed both organic manure and inorganic fertilizer are in consonance with the present study (Njoku, et al., 2008b; Al-Hawas et al., 2012).

Table 2: The effect of abattoir wastewater addition to gasoline-treated soil on photosynthetic pigments in the leaves of cowpea seedlings grown on such soil

\begin{tabular}{|c|c|c|c|c|c|c|c|c|}
\hline \multirow{2}{*}{$\begin{array}{l}\text { Gasoline Conc. in soil } \\
(\% \mathrm{v} / \mathrm{w} \mathrm{ml} / \mathrm{g})\end{array}$} & \multicolumn{2}{|c|}{ Total chlorophyll (mg/g) } & \multicolumn{2}{|c|}{ Chlorophyll a (mg/g) } & \multicolumn{2}{|c|}{ Chlorophyll b (mg/g) } & \multicolumn{2}{|c|}{$\beta$-Carotene $(\mathrm{mg} / \mathrm{g})$} \\
\hline & (PMS) & $(\mathbf{P M S})+\mathrm{AWW}$ & (PMS) & (PMS) + AWW & (PMS) & (PMS) + AWW & (PMS) & (PMS) $+\mathrm{AWW}$ \\
\hline 0.00 & $288.33 \pm 0.1$ & $320.3 \pm 0.8$ & $2.40 \pm 0.25$ & $2.90 \pm 0.25$ & $239 \pm 0.15$ & $269 \pm 0.25$ & $3.40 \pm 0.10$ & $3.70 \pm 0.27$ \\
\hline 0.10 & $221.33 \pm 0.5^{\mathrm{a}}$ & $284.0 \pm 0.4^{\mathrm{b}}$ & $2.35 \pm 0.10^{\mathrm{a}}$ & $2.83 \pm 0.70^{b}$ & $237 \pm 0.21^{\mathrm{a}}$ & $257 \pm 0.10^{\mathrm{b}}$ & $2.50 \pm 0.20^{\mathrm{a}}$ & $2.73 \pm 0.10^{\mathrm{b}}$ \\
\hline 0.25 & $207.13 \pm 0.3^{\mathrm{a}}$ & $264.6 \pm 0.9^{\mathrm{b}}$ & $2.21 \pm 0.90^{\mathrm{a}}$ & $2.70 \pm 0.50^{\mathrm{b}}$ & $226 \pm 0.06^{a}$ & $236 \pm 0.06^{b}$ & $2.47 \pm 0.00^{a}$ & $2.40 \pm 0.00^{b}$ \\
\hline 0.50 & $201.54 \pm 0.9^{a}$ & $256.7 \pm 0.7^{\mathrm{b}}$ & $2.10 \pm 0.40^{\mathrm{a}}$ & $2.21 \pm 0.50^{\mathrm{b}}$ & $229 \pm 0.06^{\mathrm{a}}$ & $239 \pm 0.10^{b}$ & $4.70 \pm 0.60^{\mathrm{a}}$ & $4.90 \pm 0.11^{\mathrm{b}}$ \\
\hline 1.00 & $192.67 \pm 0.4$ & $247.6 \pm 0.2^{\mathrm{b}}$ & $3.03 \pm 0.60^{\mathrm{a}}$ & $3.30 \pm 0.70^{b}$ & $230 \pm 0.06$ & $239 \pm 0.15^{b}$ & $5.40 \pm 0.00$ & $5.57 \pm 0.12^{b}$ \\
\hline 1.50 & $189.33 \pm 0.9^{\mathrm{a}}$ & $238.3 \pm 0.3^{b}$ & $2.33 \pm 0.60^{\mathrm{a}}$ & $2.81 \pm 0.23 \mathrm{~b}$ & $219 \pm 0.06^{a}$ & $225 \pm 0.15^{b}$ & $3.00 \pm 0.62^{a}$ & $2.89 \pm 0.14^{b}$ \\
\hline 2.00 & $175.00 \pm 0.5^{\mathrm{a}}$ & $229.6 \pm 0.1^{\mathrm{b}}$ & $1.00 \pm 0.70^{\mathrm{a}}$ & $1.50 \pm 0.20^{\mathrm{b}}$ & $150 \pm 0.06^{\mathrm{a}}$ & $200 \pm 0.15^{b}$ & $2.60 \pm 0.63^{\mathrm{a}}$ & $2.66 \pm 0.54^{b}$ \\
\hline
\end{tabular}

Values are expressed as mean $\pm \mathrm{SD}$ of five determinations. $\mathrm{a}=$ values significantly lower than those of control at $\mathrm{P}<0.05 ; \mathrm{b}=$ values significantly lower than the corresponding gasoline treatment; $\mathrm{n}=$ number of seedlings used per assay.

The activities of $\alpha$-amylase and starch phosphorylase in the leaves of cowpea seedlings grown in gasoline contaminated soil (Figure 2) decreased significantly $(\mathrm{p}<0.05)$ compared to seedlings in control group. The present finding agrees with the report of Achuba (2006). Treatment of gasoline contaminated soil with abattoir wastewater increased the activities of $\alpha$ amylase and starch phosphorylase compared with seedlings exposed to gasoline alone groups.
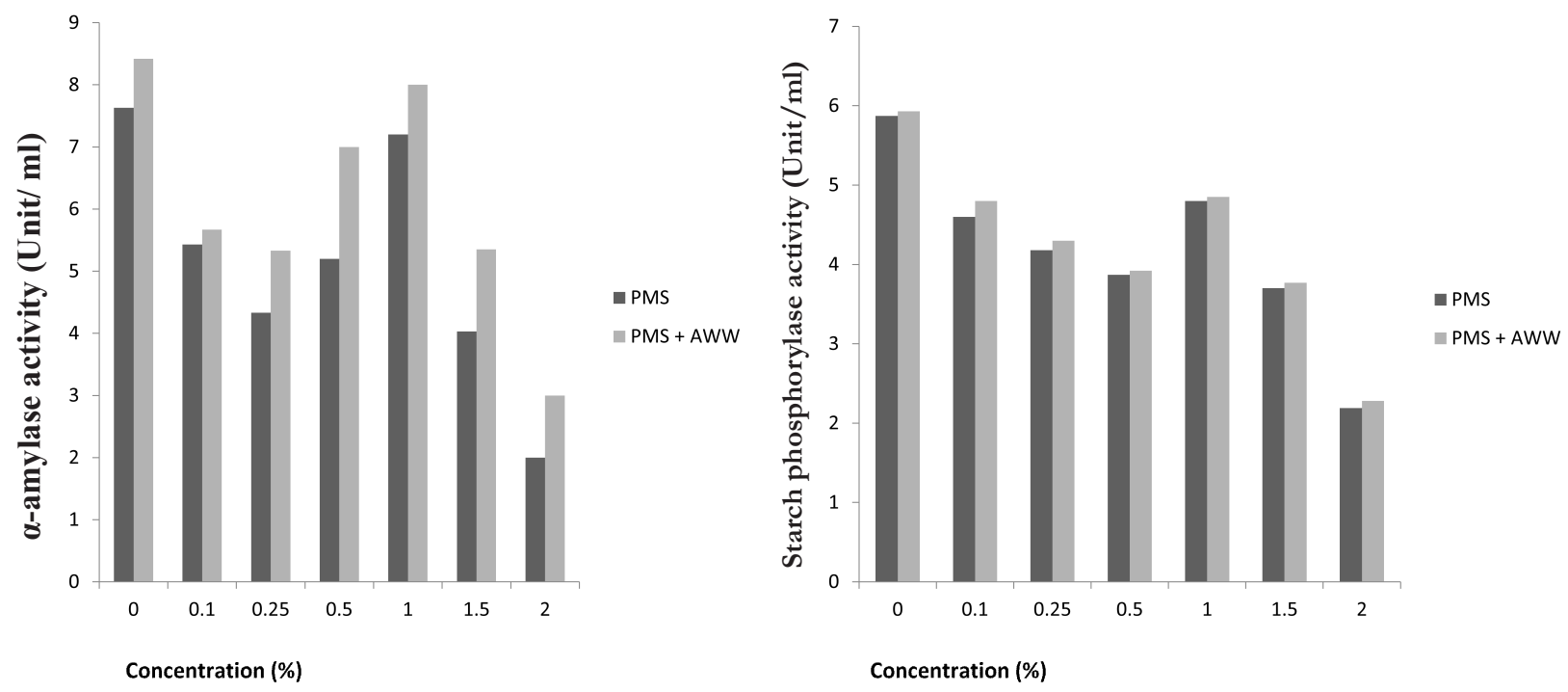

Figure 2: Effect of abattoir wastewater addition to gasoline treated-soil on the activities of $\alpha$ amylase and starch phosphorylase in the leaves of cowpea seedlings grown on such soil 
Environmental stress is associated with metabolic imbalances that can cause oxidative damage in plants (Olubodun and Eriyamremu, 2015). This is because stress in plants causes excessive generation of reactive oxygen species (Al-Hawas et al., 2012). Achuba and Osakwe (2003) reported that excessive formation of reactive oxygen species predisposes living organisms to lipid peroxidation. Therefore, lipid peroxidation is a major consequence of free radical generation (Achuba and Otuya, 2006). The present study shows that contamination of soil with gasoline caused increase in lipid peroxidation in cowpea seedlings (Table 2). Higher levels of lipid peroxidation have been reported in the radicle of germinating beans grown in soil contaminated with crude oil (Olubodun and Eriyamremu, 2015). Treatment of gasoline polluted soil with abattoir wastewater significantly decreased lipid peroxidation in the hydrocarbon exposed cowpea seedlings.

Plants possess antioxidant enzymes such as superoxide dismutase (SOD) and catalase for protection against the damaging effects of reactive oxygen species (Asada, 1994). In this study (Figure 3) exposure to gasoline treated soil increased the activities of SOD and catalase in cowpea seedlings at lower contamination levels. This corroborates the result of the work done by Al-Hawas et al (2012). The initial increase in the activities of these enzymes may be due to homeostatic adjustment by the cell to protect itself against the increasing levels of free radical toxicity (Achuba and Otuya, 2006). However, at higher contamination levels, SOD and catalase activities decreased significantly as compared to the control. Olubodun and Eriyamremu (2015) had reported a decrease in the activity of SOD in seedlings exposed to hydrocarbon treated soil. However, at higher concentrations, the capacity of the cell to deal with the increasing concentration of ROS may have been compromised (Nwaogu and Onyeze, 2014) and this may account for the decrease observed at these contamination levels. Treatment with abattoir wastewater (AWW) counteracted the effect of gasoline treatment of soil on the cowpea seedlings. However, it did not substantially restore the activity of the antioxidant enzymes towards the control values.
Gasoline treatment of soil reduced xanthine oxidase activity. This agrees with the findings of Achuba (2008). Xanthine oxidase converts xanthine into uric acid. Therefore, the reduction in xanthine oxidase activity suggest the reduced ability of the plant cell to deal with reactive oxygen species as uric acid is a known antioxidant (Achuba, 2008) . Moreover, treatment with abattoir wastewater enhanced the activity of xanthine oxidase, though it did not restore the values obtained towards the control values

\section{CONCLUSION}

Treatment of gasoline contaminated soil with abattoir wastewater substantially improved the morphological and biochemical profiles of cowpea seedlings. This study demonstrated that abattoir wastewater could mitigate the adverse effects of gasoline on exposed plants.

\section{REFERENCES}

Achuba, F.I. 2014. Petrol Products in soil mediated oxidative stress in cowpea (Vigna unguiculata) and Maize (Zea mays) Seedlings. Open Journal of Soil Science, 4: 417-435.

Achuba, F.I. and Okoh, P.N. 2014. Effect of petroleum products on soil catalase and dehydrogenase activities. Open Journal of Soil Science 4,399-406.

Achuba, F.I. and Otuya, E.O. 2006. Protective Influence of Vitamins against Petroleuminduced free radical toxicity in rabbit. The Environmentalist, 26, 295-300.

Achuba, F.I. 2010. Spent engine oil mediated oxidative stress in cowpea (Vigna unguiculata) Seedlings. Electronic Journal of Environmental, Food and Agricultural Chemistry, 9: 910-917.

Achuba, F.I. 2006. The Effect of sub lethal concentrations of crude oil on the growth and metabolism of cowpea (Vigna unguiculata) seedlings. Environmentalist, 26: 17-20.

Achuba, F.I., Peretiomo-Clarke, B.O. and Ebokaiwe, P. 2005. Pollution induced oxidative stress in African catfish (Clarias heterobranchus). European Journal of Scientific Research, 8, 52-73.

Achuba, F.I., and Peretiomo-Clarke, B.O. 2007. Effect of spent engine oil on soil catalase 
and dehydrogenase activities. International Agrophysics. 22: 1-4.

Achuba, F. I. 2008. African land snail Achatina marginatus, as bioindicator of environmental pollution. North- Western Journal of Zoology 4 (1): 1-5

Achuba, F.I. and Osakwe, S.A. 2003. Petroleum induced free radical toxicity in African catfish (Clarias garieponus). Fish Physiology and Biochemistry: 29: $97-103$

Achuba F.I. and Ekute B.O. 2017. Effect of abattoir wastewater on the metabolic status of cowpea seedlings. Proceedings of the fourth Delta State University Faculty of Science International Conference. pp 98-103

Adeleye, I. O. A. 1991. Dried poultry droppings as a source of dietary nitrogen for sheep fed corn-cobs based diets. West African Journal of Biological and Applied Chemistry, 36 (1):1932.

Adam, G., Gamoh, K., Morris, D.G. and Duncan, H. 2002. Effect of alcohol addition on the movement of petrol hydrocarbon fuels in soil. Science of Total Environment, 286(1/3): 15-25.

Adedokun, O.M. and Ataga, A.E. 2007. Effects of amendments and bioaugumentation of soil polluted with crude oil, automotive gasoline oil, and spent engine oil on the growth of cowpea (Vigna unguiculata L. Walp). Scientific Research and Essay, 2(5):147149.

Agbogidi, O.M., and Eshegbeyi, O.F. 2006. Performance of Dacryodes edulis seeds and seedlings in a crude oil contaminated soil. L. sustainable for., International Journal of Science and Nature, 22(3/4):1-14.

Agrawal, S.B. 1992. 'Effect of Supplemental UV-B radiation on photosynthetic pigment, protein and glutathione contents in green algae. Environmental and ExperimentalBotany, (32):137-143.

Al-Hawas, G.H., Shukry, W.M. and Azzoz, M.M. 2012. The effect of crude oil on germination, growth and seed profile of jojoba (Simmodsia chinensis). Plant Science Journal (1):20-35.

Alrumman, S.A., Standing, D.B., Paton G.I. 2015. Effects of hydrocarbon contamination on soil microbial community and enzyme activity. Journal of King Saud University Science 27, 31-41

Amal, A.M., Amira, A.H. and Hawa, O.E. 2012. Ecophysiological responses of grey mangrove (Avicennia marina) (Forssk.) Vierh. to oil pollution at Ras Mohammed protective area. Report and Opinion; 4(8):4356.

Anoliefo, G.O. and Edegbai, B.O. 2000. Effect of spent engine oil as a soil contaminant on the growth of two egg plant species. Journal of Agriculture, Forestry and Fisheries, (1): 21-25.

Asada, K. 1994. Production and action of active oxygen species in photosynthetic tissues. In C.H Foyer and P.M. Mullineaux, (eds), causes of photooxidative stress and amelioration of defense systems in plants, CRC Press, Boca Raton, pp.77-104.

Bamidele, J.F. and. Agbogidi O. M 2000. Toxicity of odidi petroleum oil and its water soluble fraction on three aquatic macrophytes. Nigerian Journal of Science and Environment, 2:113-121

Bartha, R. 1986. Biotechnology of petrol pollutant biodegradation. Microbial Ecology 12:155-172.

Crapo, J.D., McCord, J.M., Fridovich, I. 1978. Preparation and assay of superoxide dismutases. Methods in Enaymology. (53): 382-393.

Duxbury, A. C., and Yentsch, C. S. 1956. Plankton pigment nomographs. Journal of Marine Research. 15(4): 92-101.

Ekpo, F.E., Nya, E.J. 2012. Effect of poultry manure amendments on diesel oil polluted soil on germination and growth performance of forest trees. Journal of Research in Environmental Science and Toxicology, 1(17);195-200.

Eyidogan, M., Ozsezen, A., Canakci, M. and Turkcan, A. 2010. Impact of alcohol gasoline fuel blends on the performance and combustion characteristics of an SI engine. Fuel 89 (10); 2713.

Gupta RP, Gigras H, Mohapatra, GV, Kumar, A, Chauhan B. 2003. Microbial amylases: A biotechnological perspective. Process Biochemistry (38):1599-1616.

Heath, R.L., Packer, L. 1968. Photoperoxidation in isolated chloroplasts.kinetics and 
stoichiometry of fatty acid peroxidation. Archive of Biochemistry and Biophysics (125):189-198.

Havaux M. 1998. Carotenoids as membrane stabilizers in chloroplasts. Trends in Plant Science (3):147-151.

International Agency for Research on Cancer (IARC). 1989. Gasoline. Inche, 45:159.

Iquatt, C. B.; Oyewole, O. A. and Abioye, O. P. 2006. Bioremediation of petrol polluted soil (a review). International Journal of Natural and Applied Sciences 1(1):21-25.

Ismailov, N. M. (1985). Biodegradation of oil hydrocarbons in soil inoculated with yeasts. Microbiology (54): 670-675.

Ijah, U. J. J. and Antai, S. P. 2003. The potential use of chicken-drop microorganism for oil spill remediation. The Environmentalist 23:89-95.

Ijah, U. J. J and George, B. G. 1998. Potentials of yeast isolates in decontaminating crude oil spilled soil. Nigerian Journal of Science Technology 1(1):1-9.

Ijah, U. J. J. and Ndana, M. 2003. Stimulated biodegradation of crude oil in soil amended with periwinkle shells. The Environmentalist 23:249-254.

Keller, J. and Lamprecht, R. 1995. Road dust as an indicator for air pollution transport and deposition: An application of SPOT imagery. Remote Sensing of the Environment. 54:1-12.

Leahy, J.G., and Colwell, R.R. 1990. Microbial degradation of hydrocarbons in the environment. Microbiological Reviews 54(3): 305-315.

Liu, P. G., L. Whang, T. Chang C. C., Tseng, P. and Shung S. 2009. Verification of necessity for bioaugmentation-Lessons from two batch case studies for bioremediation of diesel-contaminated soils. Journal of Chemical Technology and Biotechnology. 84: 808-819.

Lichtenthaler, H.K. 1987. Chlorophylls and carotenoids: pigments of photosynthetic membranes. Methods in Enzymology 148:350-382.

Lowry, O.H., Rosebrough, N. J., Farr, A. L., and Randall, R. J. 1951. Protein Measurement with the Folin Phenol Reagent Journal of Biological Chemistry 193(3), 265-275
Maliszewska-Kordybach, B., Smreczak, B., and Klimkowicz-Pawlas, A. 2009. Concentrations, sources, and spatial distribution of individual polycyclic aromatic hydrocarbons (PAHs) in agricultural soils in the Eastern part of the EU: Poland as a case study. Science of the TotalEnvironment, 407: 3746-3753.

Makoi, J.H. and Ndakidemi, P.A. 2008. Selected soil enzymes: Examples of their potential roles in the ecosystem. African Journal of Biotechnology 7: 181-191.

Misra, H.P. and Fridovich, I. 1972. The Role of Superoxide in the Auto-oxidation of Epinephrine and a Simple Assay for Superoxide Dismutase. Biochemical Journal, 247: 3170-3175.

Michalcewicz, W. 1995. The effects of diesel oil on number of bacteria and actinomyces and biomass soil microorganisms (in Polish). PZH. 46(1), 91.

Njoku, K.L., Akinola, M.O. and Oboh, B.O. 2008a. Germination, Survival and growth of accession of Glycine max L. (Merril) (Soybean) and Lycopersicon esculentum L. (Tomato) in crude oil polluted soil. Research Journal of Environmental Toxicology 2(2): 77-84.

Njoku, K.L., Akinola, M.O. and Oboh, B.O. 2008b. Growth and performance of Glycine max L. (Merill) in crude oil contaminated soil augmented with cow dung. Nature and Science. 6(1):48-58.

Nwaogu, L.A., Onyeze, G.O.C. and Nwabueze, R.N. 2008. Degradation of diesel oil in polluted soil using Bacillus subtilis. African Journal of Biotechnology. 7(12): 19343.

Nwaogu, L.A., Onyeze, C.E., Alisi, C.S., Ijeh, I.I. and Onyeze, G.O.C. 2008. Petrol hydrocarbon induced changes in tissues of the native fowl (Gallus domesticus) following chronic exposure. Nigerian Journal of Biochemistry and Molecular Biology. 23(1): 42-46.

Nwaogu, L.A., and Onyeze, G.O.C. 2014. Effect of chronic exposure to petroleum hydrocarbon pollution on oxidative stress parameters and histology of liver tissues of native fowl. International Journal of Biochemistry Research and Review 4(3): 193 43. 
Niyogi, K.K. 1999. Photoprotection revisited: Genetic and molecular approaches. Annual Review of Plant Physiology and Plant Molecular Biology 50: 333-359.

Odjegba, V.J. and Sadiq, A.O. 2002. Effect of spent engine Oil on the growth parameters, chlorophyll and protein levels of Amaranthus hybridus L. The Environmentalist. 22: 23-28.

Olubodun, S.O. and Eriyamremu, G.E. 2015. Assessment of single extraction methods for the prediction of bioavailability of metals to Vigna unguiculata (bean) grown on crude oil contaminated soil. Bayero Journal of Pure and Applied Sciences. 8(1): 65 $-71$

Peretiemo-Clarke, B.O. and Achuba, F.I. 2007. Phytochemical effect of petroleum on peanut (Arachis hypogea) seedlings. Plant Pathology Journal, 6: 179-182.

Rani, P., Meena, U.K., Karthikeyan, J. 2004. Evaluation of Antioxidant Properties of Berries. Indian Journal of Clinical Biochemistry, 19: 103-110.

Rowland, A.J., Berland, A.M. and Lea, P.J. 1988. 'Changes in amino acids, amines and proteins in response to air pollutants,' in S.Schulte-Hosted N.M. Darrall, L. W. Blank, and A.R. Wellburn (eds.). Air Pollutants and Plant metabolism. Elsevier, London,pp 189-211.

Schmeink, B. and Wild, A. 1990. 'Studies on content of free amino acids in needles of undamaged and damaged spruce trees at a natural habitat. Journal of Plant Physiology 136: 66-71.

Seklemora, E., Pavlora, A. and Koracheva, K. 2001 . Biostimulation-based bioremediation of diesel fuel field demonstration. Biodegradation 12:311-316.

Sharma, P., Dubey, R.S. (2005) Pb toxicity in plants. Brazilian Journal of Plant Physiology 17:35-52.

Sivaraj, R, Kumar, K.S and Radhakrishna A. 2014. An investigation of growth and yield of Helianthus annus on diesel contaminated soil and bioremediated diesel contaminated soil. World J Pharm Res 3(10):1530-1544.

Sun, W.H., Lo, J.B., Robert, FM., Ray, C. and Tang, C.S. 2004. Phytoremediation of petrol hydrocarbons in tropical coastal soil: I. Selection of promising woody plants. ESPR-Environmental Science and Pollution Research11(4): 260- 266.

Singh, B.B. and Steinnes, H. 1976. Uptake of trace element by barley in Zinc polluted soil. Soil Science 121(1):38-43.

Tyczkowsk1, A. 1993. Remove of soil and underground water contamination with refinery products by physical chemical and biotechnological method (in Polish). Ekologia i Technika. 3-10.

Tietz, N.W. 1982. Fundamentals of clinical chemistry. $2^{\text {nd }}$ Edition, W.B. Saunders company. USA. pp 849-944

Ukpaka, C.P. and Ibiso, E. 2013. Adsorbent in bioremediation of crude oil polluted environment: influence of physicochemical characteristics of various saw dusts. International Research Journal of Biotechnology 3(7):124-141.

Umanu, G., Owoseni R.A. 2013. Effects of abattoir effluent on microbial degradation of diesel oil in tropical agricultural soil. Pacific Journal of Science and Technology 14(1):604-612.

Wang, Z. and Stutte, G.W. 2011. The role of carbohydrates in active osmotic adjustment in apple under water stress. Journal of American Society of Horticultural Science 117: 816-823.

Wyszkowska, J. and Kucharski, J. 2000. Biochemical Properties of soil contaminated by gasoline. Polish Journal Environmental Studies, 9(6): 476-485.

Wyszkowski, M. and Ziolkowska, A. 2008. Effect of gasoline and diesel oil on content of organic carbon and mineral components in soil. American- Eurasian Journal of Sustainable Agriculture, 2(1): 54-60.

Xiao, Z., Storms, R. and Tsang, A. 2006. A quantitative starch-iodine method for measuring alpha-amylase and glutathione activities. Annals of Biochemistry. (6) 351148.

Ye, Y. and Tam, N.F. 2007. Effect of used lubricating oil on two mangroves aquiems. Journal of Environmental Science 19: 13551360. 